ANTUNES, Caio. A Escola do Trabalho: Formação Humana em Marx. Campinas, SP: Papel Social, 2018.

\title{
PARA ENTENDER A ESCOLA DO TRABALHO
}

DOI: http://dx.doi.org/10.9771/gmed.v12i3.36489

\section{Leonardo Carlos de Andrade}

Essa resenha tem como objeto o livro A Escola do Trabalho: Formação Humana em Marx, que foi fruto da pesquisa de doutorado elaborada por Caio Antunes na Faculdade de Educação da UNICAMP, a qual traz à tona à essência dos escritos marxianos, minuciosamente desenvolvida pela dialética do método da economia política. Caio Antunes é professor da Faculdade de Educação Física e Dança da Universidade Federal de Goiás e desenvolve pesquisas sobre Trabalho e Educação; Teoria Social e Marx.

Como ponto de partida, tomamos o conto de Procuspo, que relata um curioso caso da mitologia grega, onde um morador da floresta tinha uma estranha mania de esticar seus hóspedes pequenos para caber em camas grandes, e de cortar os hóspedes grandes para caber em camas pequenas. Iniciamos essa resenha, adiantando que ao contrário de Procuspo, esse livro apresenta uma coerente análise da escola do trabalho, sem "esticar" ou mesmo "cortar" o tema central, mas apresentando uma síntese na medida ideal à luz da tradição marxista.

A obra versa sobre a "escola do trabalho", e tem por objetivo principal discutir o papel do trabalho na formação humana. Em uma leitura para além da aparência do título, compreendemos que o jogo de palavras adianta o conteúdo da obra, que no trabalho "Escola do Trabalho" os seres humanos criam a si próprios e se humanizam. A essência humana se faz na essência do trabalho, em outras palavras o ser histórico e social está atrelado as produções e reproduções que a humanidade complexificou através dos tempos, na relação indissociável entre ser humano e natureza.

Caio Antunes, buscou desvelar as consonâncias entre trabalho e formação humana em uma pesquisa bibliográfica-histórica, de natureza filosófica que se sustenta, prioritariamente, no conjunto de obras marxianas. Nas palavras do autor, a demanda dessa pesquisa, e consequentemente do livro, emanou da necessidade radical da transformação social, da qual a retomada das bases marxianas são de fulcral importância.

No primeiro capítulo, nos deparamos com uma leitura rigorosa ao mesmo tempo em que agradável acerca da categoria trabalho como pressuposto do ser social. O autor ressalta a relação existente entre as dimensões biológicas e sociais do ser humano, se referindo a priori das pulsões existentes e a busca pela satisfação destas. As pulsões incidem-se, ora sendo de ordem natural, ora sendo de ordem humana, sabendo que os objetos essenciais, externos ao ser, confirmam suas forças essenciais.

Antunes (2018) reforça veemente que o ser humano estabelece uma espécie de metabolismo com a natureza, sendo que ele depende da natureza ao mesmo tempo que é natureza. A natureza proporciona o local e o campo de atuação, pelo meio universal que é o trabalho. Para Marx (2004), a natureza é o meio de 
vida imediato e o instrumento de sua atividade vital, esta é o corpo inorgânico do ser humano, que é orgânico por natureza, constituem uma unidade.

Todavia, elucidando a lógica dialética materialista, na busca pela satisfação, transformando a natureza circundada o ser humano produz necessidades próprias, cada vez mais elaboradas. Por conseguinte, Antunes (2018) faz uma síntese entre a articulação do orgânico e o inorgânico. O ser humano em um dado patamar do desenvolvimento da sociedade tem uma relação mediata com a natureza por intermédio de outros seres humanos, assim seu acesso é dado pela natureza humana indissociável no natural. Portanto a carência e a necessidade compõem o que Marx (2004) denomina como natureza humana, pois o ser humano veio-a-ser e se aprendeu como ser genérico ${ }^{2}$.

Nesse enredo, apresenta sua categoria fundante de análise, o trabalho. O "domínio" da natureza é um domínio subordinado, e quanto maior a extensão do domínio, maior é a subordinação. O processo de humanização da natureza é, por conseguinte, naturalmente humano e humanamente natural. Em outras palavras, o trabalho é uma espécie de relação de mediação, ou como o autor denomina, um metabolismo entre o ser humano e a natureza, metabolismo este capaz de produzir as coisas necessárias à satisfação das necessidades humanas.

Se o ser humano se forma humanamente pelo trabalho, este também é responsável pela transformação da natureza orgânica e inorgânica em natureza humana. Assim, nas palavras do autor o surgimento do ser humano, é obra do próprio ser humano. . Nesse contexto alentado, entendemos que a história é fruto da ação humana, portanto, a origem de um novo ser, o ser social está condicionado a consciência, imbricada na produção coletiva da história sabida.

A consciência é produção social de natureza ontológica e, portanto, atividade universal ao mesmo tempo que imagem teórica da concretude coletivamente produzida. Assim, no ato teleológico de trabalho, ou seja, consciente, a natureza transformada já constitui imediatamente o ser, que pelo mesmo ato se faz ser social. $\mathrm{Na}$ gênese do ser social se suprassume a natureza circundante, complexificando as relações e produções da humanidade. Assim a verdadeira história humana vem sendo forjada, de forma que as produções culturalmente elaboradas são herdadas pelas gerações futuras pelo processo de transmissão do conhecimento, via processos formativos, superando por incorporação a produção anterior.

No segundo capítulo, o autor apresenta a antítese desse ensejo, pois o desenvolvimento ontológico pelo trabalho, também promove novas elaborações em um viés de revolução econômica, ou seja, nas relações de produção entre os seres humanos. Na constituição do processo social moderno, se efetivou a separação entre ser humano e produto. Nessa nova conjuntura, ao final do processo de trabalho, o produto objetivado não pertence ao seu produtor, e concomitantemente a necessidade que incitou o trabalho não é imediatamente satisfeita.

Em síntese, para Antunes (2018) coerentemente enriquecido com os escritos de Marx (2015), o processo de separação entre ser humano e produto do seu trabalho é alienação. Por conseguinte, o autor faz um excurso teórico atento e minucioso sobre a alienação do trabalho, que interfere de forma imediata na (des)humanização. Ademais, na alienação, a totalidade do mundo tornado humano pelo trabalho não pertence ao ser humano que o produz, ou que este ser não tem acesso aos bens objetivados na sociedade. 
Esse processo engendra a própria alienação e o estranhamento do ser humano em relação à sua própria humanidade, ou seja, ao seu ser genérico.

O autor retoma os escritos de Marx (1976) e assertivamente indica que sob a humanização desumanizadora do trabalho alienado, atividade vital dos trabalhadores não é manifestação da sua vida, mas um tráfico alienado ao capital. Aqui chegamos à um ponto fulcral da obra, onde o autor destaca que o capitalismo não é a forma última de organização social, nem mesmo são inatas as condições basais dessa estrutura, mas sim uma passagem advinda de um processo histórico. Portanto, a estrutura econômica e alienante do capital surgiu, pelo movimento histórico, da estrutura econômica da sociedade feudal.

Antunes (2018), ressalta que este sistema eleva sua riqueza sem diminuir sua miséria, sabendo que pelo trabalho alienado, a riqueza é condição da miséria. Todavia, é necessário um amplo movimento social de emancipação humana, que só é viável a partir de condições práticas de garantia de acesso a todos os objetos necessários para satisfação plena. Assim, encerra o capítulo com questionamentos sintetizados na seguinte pergunta: "Como é possível confrontar o trabalho alienado construindo formas para o movimento de emancipação?” (ANTUNES, 2018).

No capítulo 3, o autor apresenta pistas e caminhos para a Educação, Consciência e Emancipação Humana. Para isso, logo nas primeiras páginas nos contagia com uma indagação catártica. O trabalho alienado constitui uma forma determinada de existência desumanizada do processo de humanização pelo trabalho, assim a consciência também se torna alienada. Todavia, exatamente em virtude dessa condição ela também pode se tornar consciência do próprio estado de alienação.

Ademais, no processo de subjetivação e objetivação, mesmo dentro de uma estrutura complexa de trabalho alienado, há possibilidade de tomada de consciência dessa situação. Este é o cume da escola do trabalho, que Antunes fez questão de elucidar por um cariz filosófico que nos lembra as palavras de Marx, doravante, o trabalhador passa pela escola do trabalho, que é dura, mas forja a resistência.

A consciência de sua condição na formulação marxiana consiste na oposição entre capital e trabalho. O proletário tudo produz, portanto somente ele é a classe imprescindível, portanto para ele é a classe verdadeiramente revolucionária. A libertação do trabalhador só pode ser obra do próprio trabalhador, e se ancora em um amplo e profundo processo formativo dos sujeitos sociais.

A essência humana é concebida pelas relações historicamente desenvolvidas entre o conjunto de seres humanos. Todavia, novas relações sociais engendram uma nova essência humana, em outras palavras outras formas de objetividade constituem outras formas de subjetividades. Nesse contexto, retoma as veredas do processo revolucionário, enfatizando que a teoria se converte em força material quando penetra as massas. Por fim, ressaltamos enfaticamente que o livro é uma rica fonte de conhecimento para aqueles estão na busca do caminho para a síntese. Oportunamente, no fim de sua obra, o autor mais uma vez embebido com os escritos marxianos, encerra o ensejo, de forma poética agitando os ânimos dos leitores revolucionários, anunciando uma vez mais que a revolução ainda está por vir.

\section{Notas:}


${ }^{1}$ Professor no Departamento de Educação Física CEPAE-UFG Universidade Federal de Goiás Mestrando em Educação Física FEFD-UFG Coordenador do Grupo de Estudos e Pesquisas em Educação Física e Infância ORCID iD: http://orcid.org/00000002-0324-6079 Email: leonardoandradeprof@gmail.com

2 Conceito embasado em Marx (2004) e explicitado por Antunes (2018, p.39).

Recebido em:22.04.2020

Aprovado em: 23.05.2020 